ISSN 2409-5613

\author{
V. V. Kurysheva, E. V. Ivanova, P. E. Prohorova \\ Ural Federal university, \\ 620002, Ekaterinburg, 19, Mira St, Russia. \\ E-mail:p.e.prokhorova@urfu.ru
}

\title{
Extractants for rare earth metals
}

The separation of trivalent rare earth metals is perhaps the most serious challenge associated with a closed fuel cycle. The choice of ligand as extractant, which must be selective and efficient in conditions of high radiation environment, plays an important role. In this review there are the main examples of extractants for $f$-elements used in the present 10-20 years.

Key words: rare earth metals, organophosphorus compounds, crown ethers, podands, calixarenes, amides of diglycolic acid.

\section{В. В. Курышева, Е. А. Иванова, П. Е. Прохорова Уральский федеральный университет, Россия, 620002, Екатеринбург, ул. Мира, 19. E-mail:p.e.prokhorova@urfu.ru.}

\section{Экстрагенты для редкоземельных металлов}

Разделение трехвалентных редкоземельных металлов, возможно, является самым серьезным вызовом, связанным с замкнутым топливным циклом. Важную роль играет выбор лиганда в качестве экстрагента, который должен быть селективным и надежным в условиях повышенной радиации среды. В данном обзоре приведены основные примеры экстрагентов для $f$-элементов, применяющихся в последнии 10-20 лет.

Ключевые слова: редкоземельные металлы; фосфорорганические соединения; краунэфиры; поданды; каликсарены; амиды дигликолевой кислоты.

(c) Kurysheva V. V., Ivanova E. V., Prohorova P. E., 2016

\section{Introduction}

In recent decades the rare earth metals (REM) are required for creating of advanced materials and technologies using catalysts, alloys, magnets, optics and lasers, rechargeable hydride batteries, electronics, efficient lighting, conversion to wind and solar energy, bio-analysis and modeling [1].

The main method of extraction of rare earth metals in the world is mineral processing [2]. However, scientists had developed ways to obtain rare earth metals from secondary raw materials, for example, from defective fluorescent lights [3], worn out hard drives of computers [4], etc.

The extraction of rare earth metals from mineral raw materials is produced by leaching with nitric, sulfuric or hydrochloric acids or by direct chlorination, the resulting phase from the leaching of rare earth metals is separated by extraction [5]. Regardless of the type of raw material from which rare earth metals were got, the actual problem today is the search of 
the most effective extractants for separation of rare earth metals.

Analysis of literature data showed that the following well known and thoroughly described in the literature complexing agents such as crown-ethers, azacrown- esters, calixarenes, Schiff bases, porphyrins, phthalocyanines and tributylphosphates and tetraoctyldiglycolamides (TODGA) can be used as extractants for rare earth metals cations.

\section{Crown ethers as extractants of rare earth metals cations}

The first representatives of the crown ethers class were described by Pederson in 1967 [6]. Since then, chemists had synthesized many new compounds with similar to crown-ethers structure and properties, for example, azacrown-esters, open chain crown-ethers (podands). Many applications of crown ethers were based on their ability to form complexes with cations of different metals. The extraction properties of the crown ethers towards the rare earth metals were discovered during the development of new methods of extraction of radioactive elements from radioactive waste, which contained a significant number of ions of the lanthanides [7].

F. Riahi and M. Bagherzadeh [8] investigated and described the extraction of some lanthanides (III): $\mathrm{La}^{3+}, \mathrm{Ce}^{3+}, \mathrm{Pr}^{3+}$, $\mathrm{Eu}^{3+}, \mathrm{Er}^{3+}$ by derivatives of 18-crown-6ether 1-4 in the presence of trichloroacetic acid in acidic solutions in the system of DMSO/water [8]. It was established that the efficiency of cations extraction by compounds 1-4 increases in the following order: $1>2>3>4$. This is understandable from the point of view of the rigidity of the molecule structure, which cyclohexyl and aromatic fragments attach to the molecules of the crown ethers.

S. V. Demin and colleagues conducted the series of studies on the extraction of alkyl derivatives by crown ethers $\mathbf{5}$ and $\mathbf{6}$ from acidic solutions in the system chloroform/water [9]. It is shown that extraction of cations of rare earth metals by dicyclohexano-18-crown-6-ether 2 and its alkyl derivatives in the presence of trichloroacetic acid is more effective than with nitric or acetic acids. The value of the recovery factor for the cerium cation was much higher than for the yttrium cation. Such regularity was observed for all derivatives of the compounds 5 and $\mathbf{6}$. The ratio of the metal cation : crown ether in all complexes is 1:1.

Simplified technology of extraction of metal cations provides its implementa-

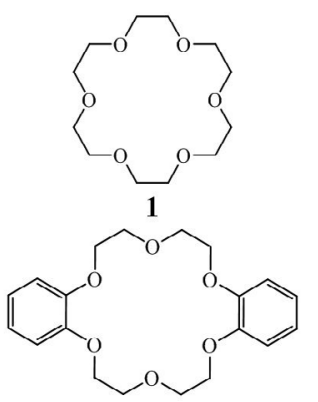

3

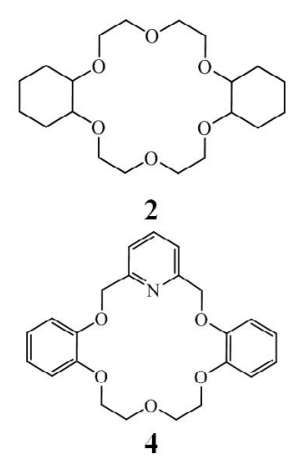



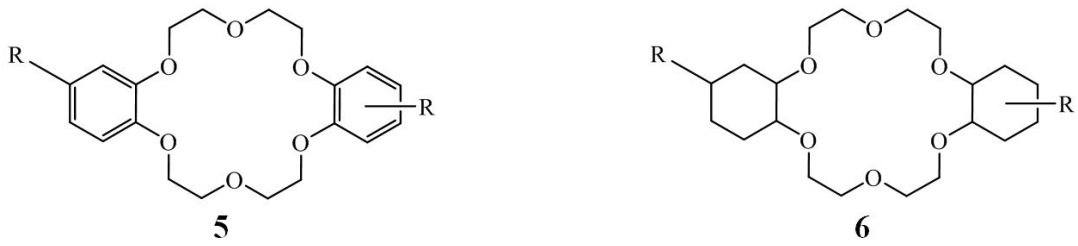

$\mathrm{R}=\mathrm{H}$, tertbutyl or isooctyl

tion in the system solid phase-liquid. So during multi-step synthesis [10] the solid phase polymer 11-13 was obtained by polymerization of the monomer $\mathbf{1 0}$. The number of units of crown ether $n$ could vary from two to four.

The experimental data obtained by J. Rey and employees, when carrying out extraction of lanthanides in acetonitrile and water, showed that compounds $\mathbf{1 2}$ and $\mathbf{1 3}$ are capable of extracting cations of lanthanides in acetonitrile to a lesser extent than compound 14. It is the best extractant for cation $\mathrm{La}^{3+}$ in acetonitrile and in water, in comparison with the other lanthanide cations. It should be noted that the compounds 12 and 13 in contrast to the 14 are not able to bind the cations of the lanthanides in the aquatic environment.

Modified diazacrown-esters can be used along with crown ethers as extractants of rare earth metals. For example, the extraction activity of compound $\mathbf{1 5}$ in relation to the lanthanides in the presence of 1-butyl-3-methylimidazole[(triflorometh yl)sulfonyl]imide is modified as follows: first, it decreases for a range of metals from La to Ho and then it increases with increasing atomic number of the element [11].

Thus, crown ethers are a class of extractants with variable selectivity in relation to extractable cations. The required level of selectivity of the crown ether is achieved by changing of the number of links of the glycol chain and introducing of a variety of substituents to its structure. Crown-ethers show the greatest efficiency under the extraction of lanthanides from solutions of trichloroacetic, acetic and nitric acids.

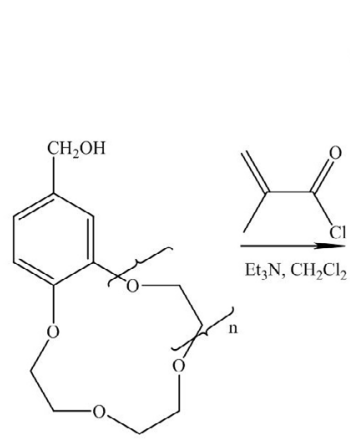

$n=1(7), 2(8), 3(9)$

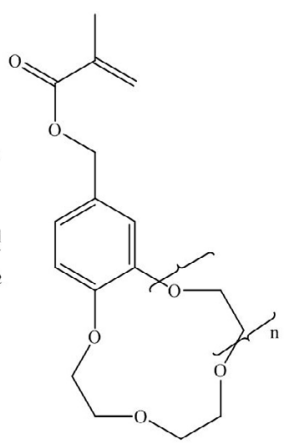

10

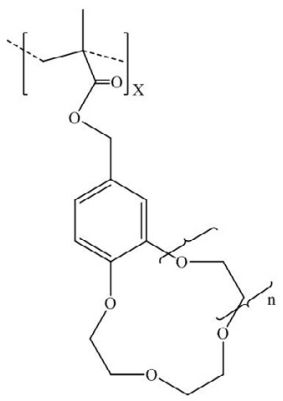

11
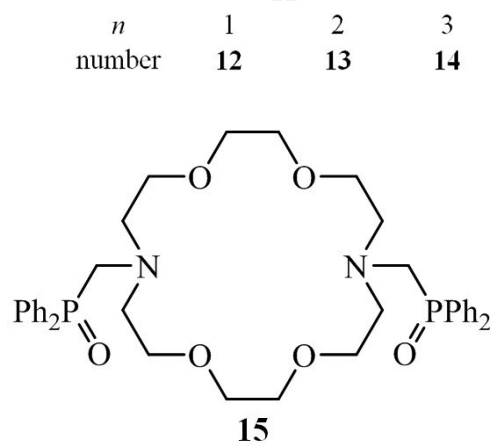


\section{Podands as extractants for cations of rare earth metals}

The open chain crown ethers or podands are considering as analogues of complexing crown ethers. Sour phosphoryl-containing podands 16, 18, 19 were described in 1989 as complexing agents for alkali metals [12]. Compound 17 and its analogues with $\mathrm{R}_{1}=$ tert-butyl has been proposed as a reagent for the selective extraction of Th(IV) from solutions of nitric acid $[13,14]$.

The extraction of rare earth metals cations from solutions of nitric, hydrochloric and perchloric acids by acidic phosphoryl-containing podands 16-19 was described by Turanov A.V. and employees [15]. They found that the efficiency of extraction of rare earth metals cations (from $\mathrm{La}(\mathrm{III})$ to $\mathrm{Lu}(\mathrm{III})$ ) from $0.01 \mathrm{M}$ solution of nitric acid with $0.01 \mathrm{M}$ solution of the extractant in dichloroethane increases in the order of $\mathbf{1 8}<\mathbf{1 6}<\mathbf{1 7}<\mathbf{1 9}$ moreover with the increase of concentration of nitric acid the extraction efficiency is reduced. Neutral phosphoryl-containing compounds 20-22 slightly extracted rare earth metals cations under these conditions. The authors also note the change of the extraction ability of the compounds 22 in used acids solutions with a concentration of $0.01 \mathrm{M}$ in the following order $\mathrm{HCl}<\mathrm{HNO}_{3}<\mathrm{HClO}_{4}$.

The process of extraction of cations of rare earth metals are affected by both: the nature of the used acids and the nature of the organic solvents. For example, the efficiency of extraction of Eu (III) with a solution of podand $23 \mathrm{e}$ in various organic solvents was increased in the next row of the solvents chloroform $<2$-ethylhexanol $<$ toluene $<$ methylene chloride $<$ dichlorobenzene $<$ dichloromethane $<$ nitrobenzene, it is due to the specific sol- vation of the podand molecules by solvent (chloroform or aliphatic alcohol) and the formation of hydrogen bonds, for example, $\mathrm{P}=\mathrm{O} \bullet \bullet \mathrm{HCCl} 3$ or $\mathrm{P}=\mathrm{O} \bullet \bullet H O R 1$.

The nature of the organic solvent also affects to the selectivity of extraction. Turnov and staff discovered that under increasing the solvated ability of organic solvent for the system with extractant $24 \mathrm{e}$ the selectivity of extraction of cations of rare earth metals increases in the following order: toluene <chloroform $<$ methylene chloride. Perhaps this is due to the fact that the complexes of heavy rare earth metals cations solvated by organic solvents to a greater extent. During the extraction of cations by the compound $24 \mathrm{e}$

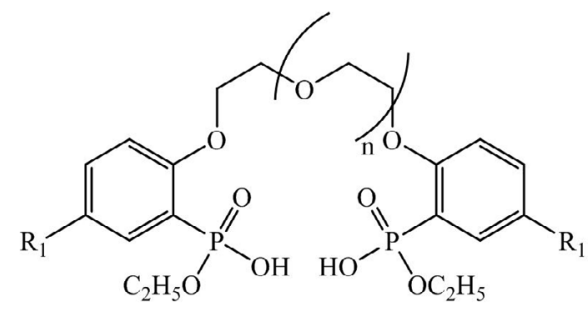

16, $n=1, \mathrm{R}_{1}=\mathrm{H} ; 17, n=1, \mathrm{R}_{1}=\mathrm{C}_{2} \mathrm{H}_{5} ; 18, n=2, \mathrm{R}_{1}=\mathrm{H}$

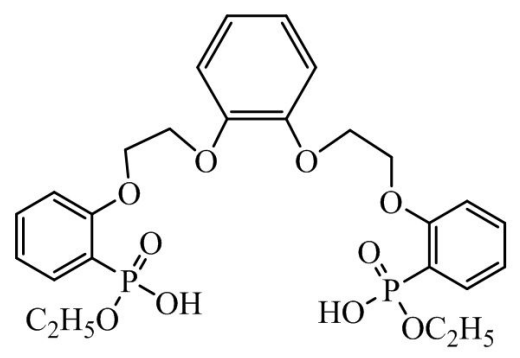

19

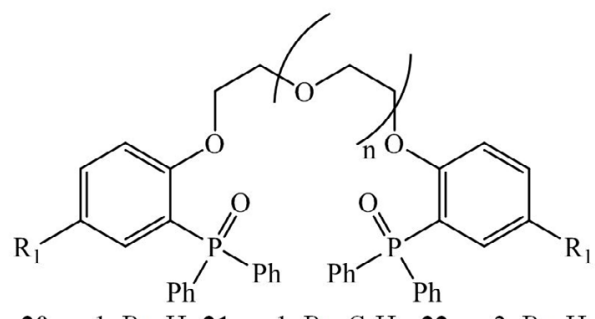

20, $n=1, \mathrm{R}_{1}=\mathrm{H} ; 21, n=1, \mathrm{R}_{1}=\mathrm{C}_{2} \mathrm{H}_{5} ; 22, n=2, \mathrm{R}_{1}=\mathrm{H}$ 
with the use of polar solvent, the extraction efficiency increases with increasing of the atomic number of rare earth element in the periodic table. For toluene (a less polar solvent), the extraction efficiency is increased only for a number of elements from lanthanum to europium, then it was fallen from terbium to lutetium.

The selectivity of the extraction may depend on the number of oxygen atoms $m$ in the polyester chain of podands. The increase $m$ in podands $24 a-d$ from one to three reduced the efficiency and selectivity of extraction of lanthanides. Increasing $m$ to four led a slight decrease of extraction efficiency for lanthanum, for the rest rare earth elements the extraction efficiency increases, which leads to higher selectivity of extraction by podand $\mathbf{2 4 d}$. For podands 23a-f with the number $m$ to 6 atoms the non-linear increase in extraction efficiency of lanthanides and its sharp decrease in the event of a connection with the compound $\mathbf{2 3 f}$ ( $m=7$ ) were observed. Selectivity of extraction is changed in the same direction for the extraction of rare earth metals cations by podans 23a-f [16].

Based on the podand with open polyester chains 25, similarly as in the case of crown-ether 7-9, it is possible to obtain a polymer 26-28 for the extraction of cations of rare earth metals in the system solid phase-liquid [10]. However, unlike the crown esther-containing polymers, polymers containing podands are able to more effective extraction of lanthanides in water. The increase of extraction efficiency of lanthanides both in water and in acetonitrile has been observed in a number of polymers $\mathbf{2 6}<\mathbf{2 7}<\mathbf{2 8}$.
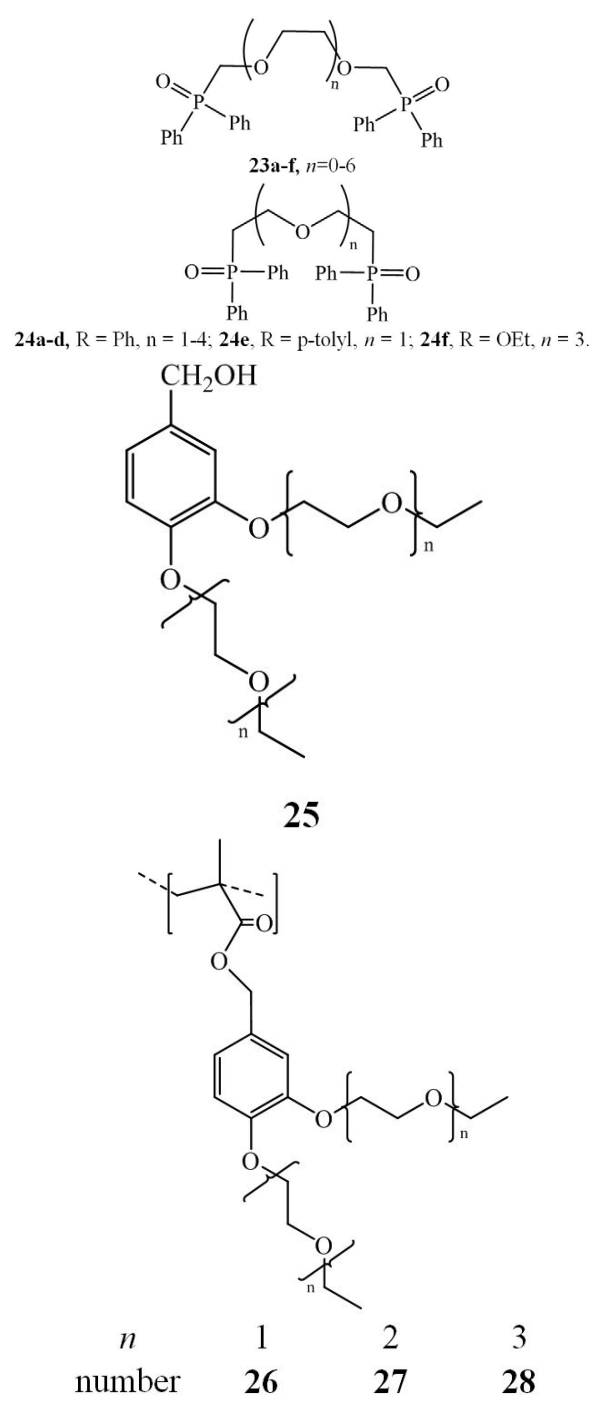

In summary above, it is worth noting that the most effective extractants for rare earth metals are phosphoryl-containing podands, the selectivity of which may depend on the number of oxygen atoms in the polyester chain of the podand as well as the nature of organic solvent. 


\section{Extraction of rare earth metals cations by modified calix[ $n$ ]arenes}

With the development of the nuclearpower industry the question about the elimination and reprocessing of nuclear waste arose acutely. The separation of actinides from lanthanides is an important step before the implementation of the transmutation technology of actinides transformation. Therefore, for extraction of radioactive elements from nuclear waste a number of selective extractants, for example, monodentate organophosphorus extractants (trioctylphosphine, TOFO) [17] were tested. However, they showed low efficiency and insufficient selectivity. Therefore, the idea of joining of phosphoryl group on the hard platform of calixarene arose to take advantage of described $[19,20]$, as well as some calixarenes with their phosphine oxides at the lower rim [21, 22].

M. Karavan and colleagues examined complexing properties of phosphonate derivatives of calix $[n]$ arenes 29-36 in relation to some actinides and lanthanides [23]. Analysis of experimental data of the cations extraction from nitric acid solution in $m$-nitrobenzotrifluoride $(m$ NBTF) showed that the efficiency of extraction by calixarenes with phosphinic substituents in the upper rim of $\mathbf{2 9 b}$ and of 29d for cations ${ }^{152} \mathrm{Eu}$ exceeds it for ${ }^{241} \mathrm{Am}$. However, increasing of the concentration of nitric acid in the solution leads to a decrease in the values of extraction<smiles>[R10]c1c(CC)cc(CP([R])([R2])=O)cc1CC(C)(C)C</smiles>

\begin{tabular}{c|c|l|l}
$n$ & $\mathrm{R}_{1}$ & \multicolumn{1}{|c}{$\mathrm{R}_{2}$} & \\
\hline 4 & propyl & methyl & 29a \\
\hline & & ethyl & 29b \\
\hline & & propyl & 29c \\
\hline & & Iso-propyl & 29d \\
\hline & & butyl & 29e \\
\hline 4 & hexyl & ethyl & 30a \\
\hline & & butyl & 30b \\
\hline 6 & methyl & ethyl & 31a \\
\hline & & butyl & 31b
\end{tabular}

synergistically effect for increasing the efficiency and selectivity of extraction [18]. Previously it has already been well studied and calixarene derivatives containing carbamoylmetylphosphin oxides in different positions of the calixarene fragments were

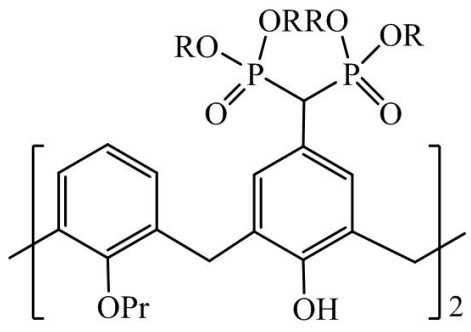

\begin{tabular}{l|l|l}
$n$ & \multicolumn{1}{|c|}{$\mathrm{R}$} & \\
\hline 4 & $\mathrm{H}$ & 32a \\
\hline 4 & Tert-butyl & 32b \\
\hline 5 & Tert-butyl & 33a \\
\hline 6 & $\mathrm{H}$ & $\mathbf{3 4 a}$
\end{tabular}

\begin{tabular}{l|l}
\multicolumn{1}{c|}{$\mathrm{R}$} & \\
\hline metyl & $\mathbf{3 5 a}$ \\
\hline ethyl & $\mathbf{3 5 b}$ \\
\hline propyl & $\mathbf{3 5 c}$ \\
\hline Iso-propyl & $\mathbf{3 5 d}$ \\
\hline butyl & $\mathbf{3 5 e}$
\end{tabular}<smiles>CCC</smiles><smiles>CCCc1cccc(Cc2cc(CP(N)(=O)O)cc(CC)c2OCC)c1OCC</smiles>

$\mathrm{R}_{1}=\mathrm{R}_{2}=$ propyl $\mathbf{6 a}$ 
ratio for compounds $29 \mathrm{e}$; for $29 \mathrm{~b}$ there is a gradual increase of the coefficient up to $0.9 \mathrm{M} \mathrm{HNO}_{3}$, which is then followed by a sharp decrease.

From a number of calixarenes with phosphine substituents at the lower rim 32a, 32b, 33a and 34a, p-tertbutylcalix [5] arene 33a has the highest extraction efficiency for ${ }^{241} \mathrm{Am}$ and ${ }^{152} \mathrm{Eu}$.

Among calixarenes with phosphonate substituents in the upper rim 35a-e has the maximum value of the extraction coefficient of europium and americium. The coefficients of extraction of ${ }^{241} \mathrm{Am}$ and ${ }^{152} \mathrm{Eu}$ were determined radiometrically using $\gamma$-radiation of the corresponding isotopes [23].

Another example of the synthesis of selective extractants based on calix[4] arene to separate actinides from lanthanides has been described by Ansari and employees [24, 25]. They received the series of pyrazine-substituted calixarenes 37-39 and examined their efficiency for the extraction of the cation $\mathrm{Eu}^{3+}$ from an aqueous solution of nitric acid.

According to research data the efficiency of extraction of cations of europium by compounds 37-39 can be displayed in the following sequence: $\mathbf{3 7}<<\mathbf{3 8}<\mathbf{3 9}$. These results can be explained by the influence of the nature of the substituent of pirazine fragment in compounds 37-39. The researchers also found that the ratio between the compounds 37-39 and cation $\mathrm{Eu}^{3+}$ in the formed complexes is $1: 1$.

However, according to $\mathrm{H}$. Huang and employees, the presence of the phosphorus atom in the structure of the extractant molecule does not allow to fully burn it, turning into accumulated solid waste [26]. The best extractants, in this case, are compounds only consisting of the atoms
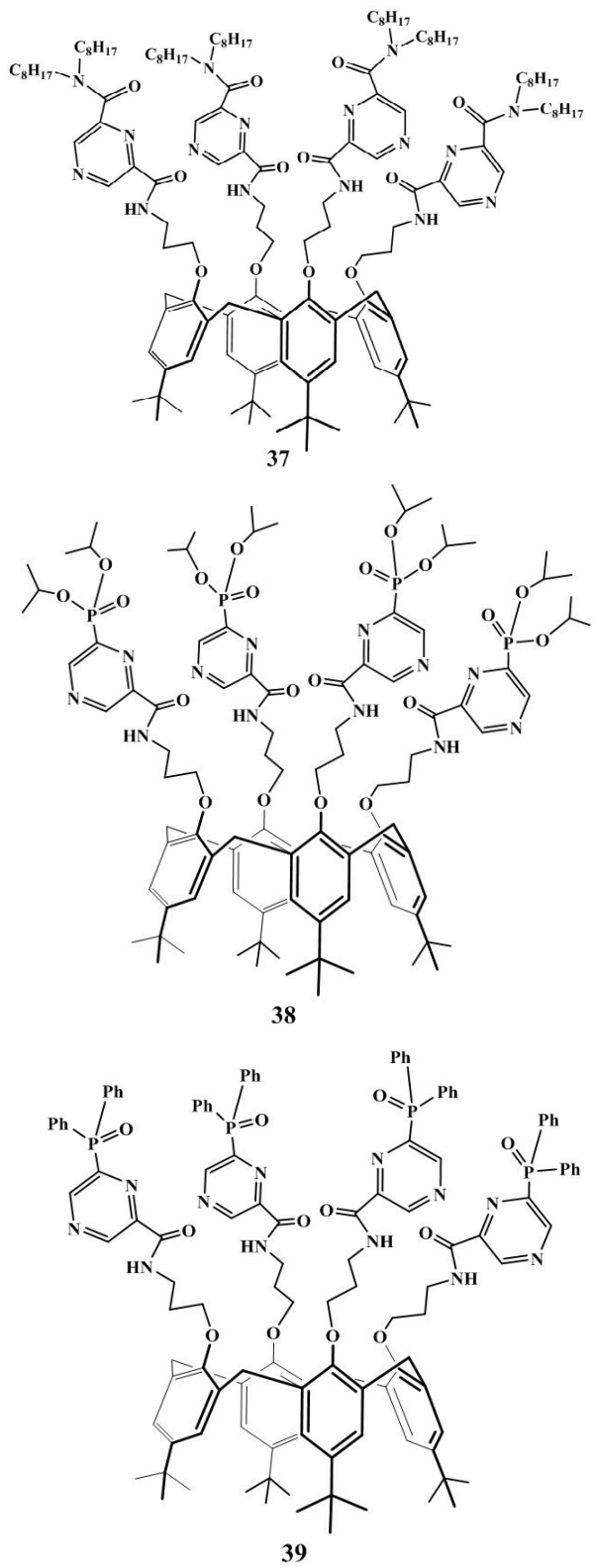

$\mathrm{C}, \mathrm{H}, \mathrm{O}$ and $\mathrm{N}$, which will turn into gaseous products after disposal. The promising easily synthesized compounds for extraction of actinides from acid solutions were considered to fit "principle CHON» diglycolamides (DGA) [27]. But due to their low selectivity DGA may not be used for the separation of actinides and lantha- 


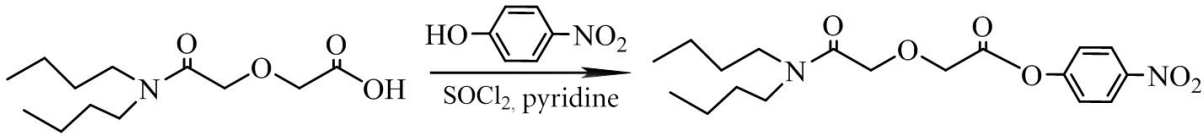

4041

nides. The introduction of diglycolamide to the molecule of calix[4]arene is a way to obtain promising compounds $\mathbf{4 3}$ for separation of actinides and lanthanides, which Huang and staff chose.

The synthesis of calix[4]arene-BDGA 43 was carried out in accordance with a scheme where the compounds $\mathbf{4 0}$ and 42 were obtained by previously described methods $[28,29]$. The study of the extraction of $\mathrm{Am}$ (III) and $\mathrm{Eu}(\mathrm{III})$ from the solution of nitric acid by the compound $\mathbf{4 3}$ was conducted using 95\% kerosene $/ 5 \%$ $n$-octanol as diluent. The results showed that the value of the extraction factor for $\mathrm{Am}(\mathrm{III})$ and $\mathrm{Eu}(\mathrm{III})$ increases with increasing concentration of nitric acid in the range from 0.5-5.0 mol/L. Ligand 43 showed higher selectivity for $\mathrm{Eu}(\mathrm{III})$ than for $\mathrm{Am}$ (III) with separation factor $\mathrm{SF}_{\mathrm{Am}(\mathrm{III}) /}$ Eu(III) in the range 4.5-7.3, that indicates its
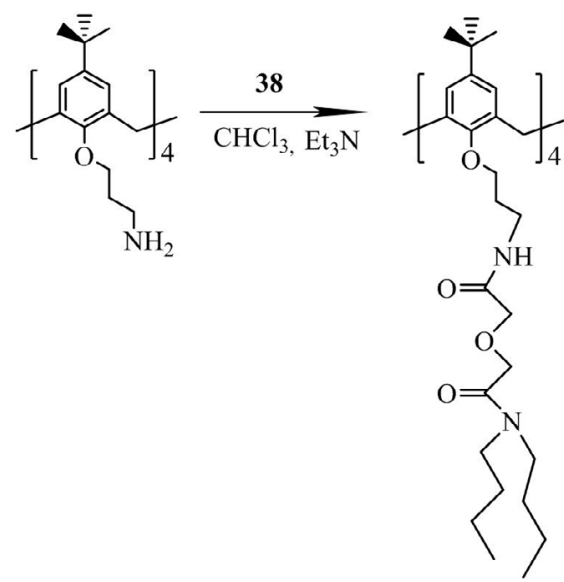

4243

effectiveness in separation of cations of the lanthanides and actinides [30].

Thus, modified calixarenes occupy one of leading positions among highly efficient and selective extractants of cations of rare earth metals.

\section{Diglycolamides are extractants}

\section{for separation of actinides and lanthanides}

Diglycolamides and their derivatives, which are promising extractants for the extraction of the lower actinides from solutions of nitric acid, have been described by $H$. Stephan and colleagues in 1991 [31]. The presence of ether oxygen between the two amide groups in the DGA increases the extraction of lower actinides due to the active education of tridentate complexes. N,N,N',N'-Tetraoctyldiglycolamide (TODGA) $\mathbf{4 4 g}$ and N,N,N',N'Tetra-2-ethylhexyldiglycolamide (TEHDGA) 44j $[32,33]$ were considered as the most promising extractants for the lower

actinides among diglycolamides. It is due to the influence of the nature of the alkyl substituents of diglycolamide.

The influence of alkyl substituents and the nature of diluent on the extraction of lanthanides and actinides by diglycolamides 44a-l was studied by Y. Sasaki and colleagues [34]. They found that compounds with the branched alkyl chain and asymmetric alkyl-phenyl amide groups have the relatively low coefficient of extraction of the cations than glycolamides with a linear hydrocarbon substituents. An extraction study of the lanthanides by 
THDGA, TODGA, TDdDGA, TEHGDA and DMDPDGA was conducted in six solvents (nitrobenzene, dichloroethane, octanol, chloroform, toluene, dodecane) using 0.04-0.1 M diglycolamide and $1 \mathrm{M}$ nitric acid solution. In every case except of THDGA in toluene, DMDPDGA in chloroform and toluene and TEGDGA in 6 diluents there was a gradual increase in the coefficient of extraction of lanthanides in increasing order of their atomic number from La to Ho, then the value of the coefficient decreases for cations ErLu. It is also worth noting that TODGA or TDdDGA dissolved in nitrobenzene, octanol and dodecane have separation factor $\mathrm{SF}(\mathrm{Lu} / \mathrm{La})$ more 100 than confirms the use of these diglycolamides for the selective separation of lanthanides. The extraction of lanthanides into chloroform or toluene showed a low value of not only recovery ratio, but also the separation factor SF (Ln/La).

Thus, an important condition affecting the extraction efficiency of lanthanides by diglycolamides is the nature of the alkyl

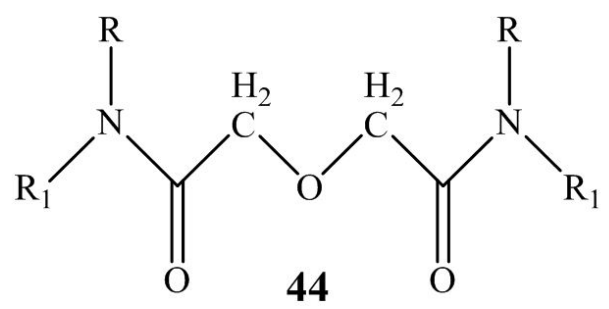

\begin{tabular}{l|l|l}
$\mathrm{R}_{1} \mathrm{R}_{1}$ & Tert-methyl & TMDGA 44a \\
\hline & Tert-ethyl & TEDGA 44b \\
\hline & Tert-propyl & TPDGA 44c \\
\hline & Tert-butyl & TBDGA 44d \\
\hline & Tert-amyl & TADGA 44e \\
\hline & Tert-hexyl & THDGA 44f \\
\hline & Tert-octyl & TODGA 44g \\
\hline & Tert-decyl & TDDGA 44h \\
\hline & Tert-dodecyl & TDdDGA 44i \\
\hline & Tert-2-ethylhexyl & TEHDGA 44j \\
\hline & $\begin{array}{l}\text { N,N'-dimethyl- } \\
\text { N,N'-diphenyl }\end{array}$ & DMDPDGA 44k \\
\hline & Tert-phenyl & TPDGA 44l
\end{tabular}

substituents of diglycolamide and used diluent.

\section{Extraction of lanthanides by organophosphorous extractants}

Since the tributyl phosphate TBP and triphenylphosphineoxide TPPO are the objects for study of extractive activity in relation to the rare earth metals cations. E. Jorjani and colleagues [35] examined the effectiveness of cations extraction of yttrium, lanthanum, cerium and neodymium by tributyl phosphate which are the main components of the waste of processing of iron ore.

Studies have shown that using different concentrations of solution of TBP in kerosene (from 0.73 to $3.65 \mathrm{~mol} \cdot \mathrm{l}^{-1}$ ), an increase in the rate of extraction factor to
TBP concentration of $3.65 \mathrm{~mol} \cdot \mathrm{l}^{-1}$ was observed [36].

In the study of extraction of rare earth metals cations by organophosphorus extractants, researchers pay attention to the synergetic effect. Synergistic extraction of trivalent lanthanides is of great interest due to the high efficiency of cations extraction by chelating agent in the presence of the neutral donor. Many of studied liquid-phase extraction processes, which have a synergistic character, were made using monodentate compounds (for example, trioctylphosphine oxide, TOPO and $\beta$-diketones). Umetani and Freiser 
<smiles>CC1=NN(c2ccc([N+](=O)[O-])cc2)C(=O)C1[N+](=O)[O-]</smiles>

45

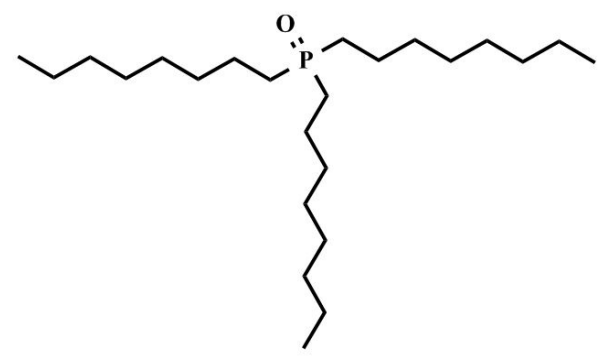

47 TOPO

studied the mixed ligand-chelate extraction of lanthanides with 1-phenyl-3-methyl-4-(trifluoroacetyl)-5-pyrazolones and some phosphine oxides [37].

The extraction of lanthanides with the mixture of picrolonic acid $\mathbf{4 5}$ with various neutral organophosphorus donors have been studied by A. Ali and staff [38]. In one of their works they have published research data of synergistic extraction of $\mathrm{Eu}(\mathrm{III})$ from mixture of cations of di-

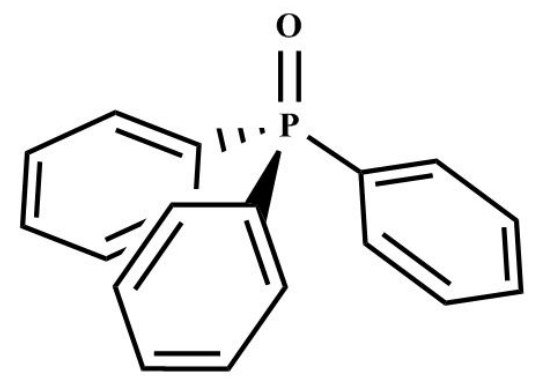

46 TPPO

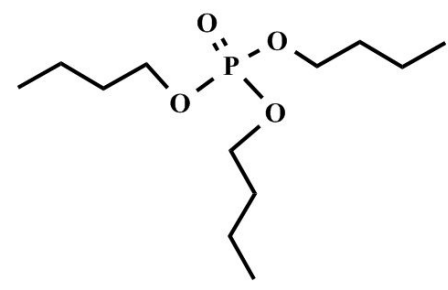

48 TBP

valent transition metals using dissolved mixture of picrolonic acid and TOPO, TPPO and TBP [39] in chloroform. The extracted particles were characterized as $\mathrm{Eu}(\mathrm{PA}) 3.2 \mathrm{TOPO}, \mathrm{Eu}(\mathrm{PA}) 3 \cdot 2 \mathrm{TPPO}$ and $\mathrm{Eu}(\mathrm{PA}) 3 \cdot \mathrm{TBP}$ [40]. The most effective extracting mixture for europium was the mixture of picrolonic acid and TOPO, the mixture of PA and TPO is less effective. A mixture of PA and TBP [41]4 showed the least ability to extraction of europium.

\section{Conclusion}

Organophosphorous extractants has gained its popularity due to relatively simple synthetic methods and low cost. For selectivity, they are largely inferior to crown-ethers and calixarenes. However, the ability of organophosphorous compounds to synergistic extraction of cations causes for further study [42].

Today the most promising extractants for rare earth metals are crown-ethers, calixarenes, podands, diglycolamides and organophosphorous compounds $[43,44]$. Modification (including the association) of their structures enables to obtain wide range of extractants which can selectively bind cations of rare earth metals. 


\section{Введение}

В последние десятилетия редкоземельные металлы (Р3М) становятся необходимыми для создания усовершенствованных материалов и технологий с использованием катализаторов, сплавов, магнитов, оптики и лазеров, перезаряжаемых гидридных аккумуляторов, электроники, экономичного освещения, конверсии ветряной и солнечной энергии, биоанализа и моделирования [1].

Основным способом добычи Р3М в мире является переработка минерального сырья [2]. Однако учеными разработаны способы получения РЗМ из вторичного сырья, например, из вышедших из строя флуоресцентных ламп [3], пришедших в негодность жестких дисков компьютеров [4] и т. д.

Извлечение редкоземельных металлов из минерального сырья произво- дят выщелачиванием азотной, серной или соляной кислотами или прямым хлорированием, полученные в результате выщелачивания Р3М разделяют экстракцией [5]. Независимо от вида сырья, из которого получают РЗМ, актуальной проблемой на сегодняшний день является поиск наиболее эффективных экстрагентов для разделения P3M.

Анализ литературных данных показал, что в качестве экстрагентов для катионов РЗМ могут быть использованы следующие хорошо известные и достаточно подробно описанные в литературе комплексообразователи, такие как краун-эфиры, азакраун-эфиры, каликсарены, основания Шиффа, порфирины, фталоцианины, трибутилфосфаты и тетраоктилдигликольамиды (TODGA).

\section{Краун-эфиры как экстрагенты катионов РЗМ}

В 1967 году Педерсоном были описаны первые представители класса краун-эфиров [6]. С тех пор химиками было синтезировано множество новых соединений, обладающих схожим с краун-эфирами строением и свойствами. Например, азакраун-эфиры, открытоцепные краун-эфиры (поданды). Большинство способов применения краун-эфиров основано на их способности образовывать комплексы с катионами различных металлов. Экстракционные свойства краун-эфиров по отношению к РЗМ были обнаружены при разработках новых способов экстракции радиоактивных элементов из радиоактивных отходов, которые со- держали значительное количество ионов лантанидов [7].

F. Riahi и M. Bagherzadeh [8] исследовали и описали экстракцию некоторых лантанидов (III): $\mathrm{La}^{3+}, \mathrm{Ce}^{3+}, \mathrm{Pr}^{3+}$, $\mathrm{Eu}^{3+}, \mathrm{Er}^{3+}$ производными 18-краун6-эфира а-д в присутствии трихлоруксусной кислоты в кислых растворах, в системе ДМСО/вода. Установлено, что эффективность экстракции катионов соединениями 1-4 увеличивается в следующем порядке: $1>2>3>4$. Это объяснимо с точки зрения жесткости структуры молекулы, которую придают молекулам краун-эфиров циклогексильные и ароматические фрагменты. 


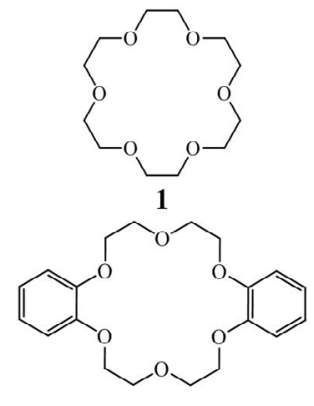

3

S. V. Demin и коллеги провели ряд исследований экстракции алкилированными производными краун-эфиров 5 и $\mathbf{6}$ из кислых растворов в системе хлороформ/вода [9]. Показано, что экстракция катионов редкоземельных металлов дициклогексано-18-краун6-эфиром 2 и его алкилированными производными в присутствии трихлоруксусной кислоты является более эффективной, чем с использованием азотной или уксусной кислот. Значение коэффициента извлечения для катиона церия намного превышало таковое для катиона иттрия. Такая закономерность была замечена для всех производных соединений 5 и 6 . Соотношение катион металла с краун-эфиром во всех комплексах равно 1:1.

Упрощенная технология экстракции катионов металлов предусматривает ее проведение в системе твердая фаза-жидкость. Так в ходе многостадийного синтеза [10] удалось получить твердофазный полимер 11-13 при по-

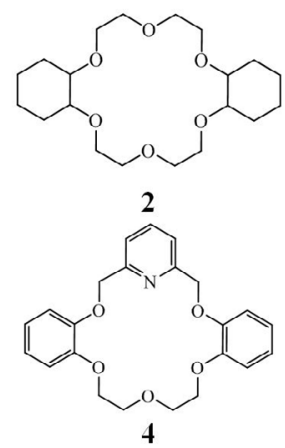

лимеризации мономера 10. Количество звеньев краун-эфира $n$ может варьироваться от двух до четырех.

Экспериментальные данные, полученные J. Rey и сотрудниками при проведении экстракции лантаноидов в ацетонитриле и воде, показали, что соединения 12 и 13 способны извлекать катионы лантаноидов в ацетонитриле в меньшей степени, чем соединение 14. Оно является наилучшим экстрагентом для катиона $\mathrm{La}^{3+}$ как в ацетонитриле, так и в воде, в сравнении с остальными катионами лантаноидов. Стоит отметить, что соединения 12 и 13 , в отличие от 14, не способны связывать катионы лантаноидов в водной среде.

Наряду с краун-эфирами в качестве экстрагентов РЗМ могут быть использованы модифицированные диазакраун-эфиры. Например, экстракционная активность соединения 15 по отношению к лантаноидам в присутствии 1-бутил-3-метилимидазолбис[(трифто рметил)сульфонил]имида изменяется

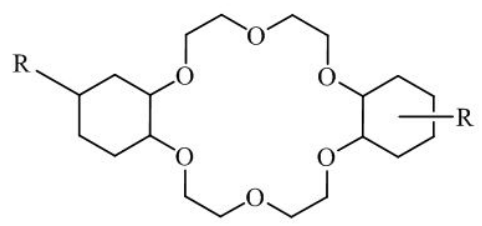

6

$\mathrm{R}=\mathrm{H}$, третбутил или изооктил 

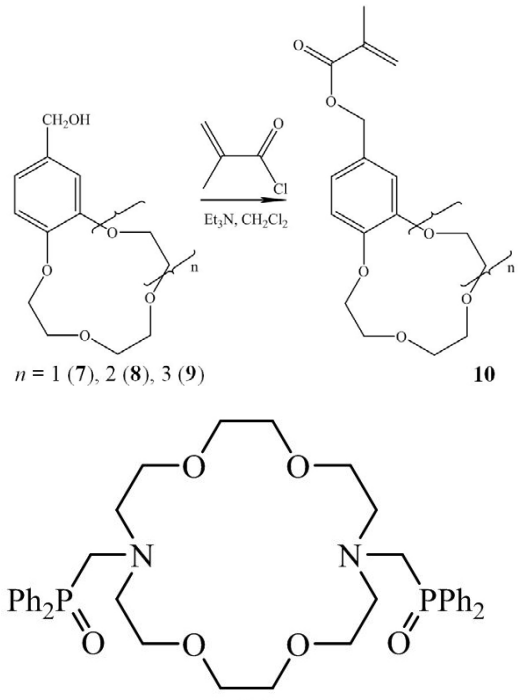

15

следующим образом: сначала понижается в ряде металлов от La до Ho, а затем повышается с увеличением атомного номера элемента [11].

Таким образом, краун-эфиры представляют собой класс экстрагентов с варьируемой селективностью по отношению к экстрагируемым катионам.

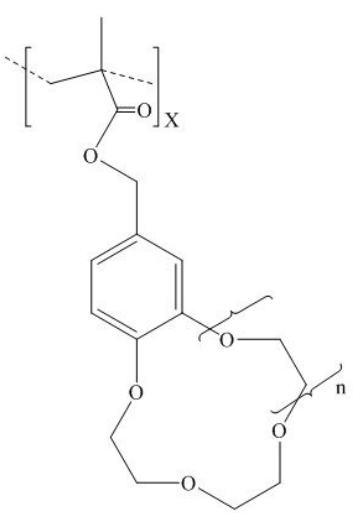

11

$\begin{array}{cccc}n & 1 & 2 & 3 \\ \text { номер } & 12 & 13 & 14\end{array}$

Требуемый уровень селективности краун-эфира достигается изменением количества звеньев гликольной цепи и введением разнообразных заместителей в его структуру. Наибольшую эффективность краун-эфиры проявляют при экстракции лантаноидов из растворов трихлоруксусной, уксусной и азотной кислот.

\section{Поданды как экстрагенты для катионов РЗМ}

В качестве комплексообразующих аналогов краун-эфиров рассматривают открыто-цепные краун-эфиры или поданды. Кислые фосфорил-содержащие поданды 16, 18, 19 были описаны в 1989 году как комплексообразователи для щелочных металлов [12]. Соединение 17 и его аналоги с $\mathrm{R}_{1}=$ третбутил было предложено как реагент<smiles>[Z1]COP(=O)(O)c1cc([R])ccc1OCCOCC(C)COc1ccc([R1])cc1P(=O)(O)OCC</smiles>

16, $n=1, \mathrm{R}_{1}=\mathrm{H} ; 17, n=1, \mathrm{R}_{1}=\mathrm{C}_{2} \mathrm{H}_{5} ; 18, n=2, \mathrm{R}_{1}=\mathrm{H}$ для селективной экстракции Th(IV) из растворов азотной кислоты $[13,14]$.

Экстракция катионов Р3М из растворов азотной, соляной и хлорной кислот кислыми фосфорил-содержащими подандами 16-19 была описана<smiles>CCOP(=O)(O)c1ccccc1OCCOc1ccccc1OCCOc1ccccc1P(=O)(O)OCC</smiles> 
А.В. Турановым и сотрудниками [15]. Ими установлено, что эффективность экстракции катионов P3M от La(III) до $\mathrm{Lu}(\mathrm{III})$ из 0,01 M раствора азотной кислоты с 0,01 М раствором экстрагента в дихлорэтане увеличивается в порядке $18<16<17<19$, причем при повышении концентрации азотной кислоты эффективность экстракции снижается. Нейтральные фосфорил-содержащие соединения 20-22 незначительно экстрагировали катионы РЗМ при этих условиях. Также авторы отмечают изменение экстракционной способности соединения II в используемых растворах кислот с концентрацией 0,01 М в следующем порядке $\mathrm{HCl}<\mathrm{HNO}_{3}<$ $<\mathrm{HClO}_{4}$.

На процесс экстракции катионов РЗМ влияет как природа используемых кислот, так и природа органических растворителей. Например, при экстракции $\mathrm{Eu}(\mathrm{III})$ раствором поданда IIe в различных органических растворителях наблюдалось увеличение эффективности экстракции Eu (III) в следующем ряду растворителей: хлороформ $<2$-этилгексанол < толуол < метиленхлорид < дихлорбензол < дихлорэтан $<$ нитробензол, что объясняется специфической сольватацией молекул поданда растворителем (хлороформ или алифатический спирт) и образованием водородных связей. Например, $\mathrm{P}=\mathrm{O} \bullet \bullet \mathrm{HCCl}_{3}$ или $\mathrm{P}=\mathrm{O} \bullet \bullet \mathrm{HOR}[16]$.

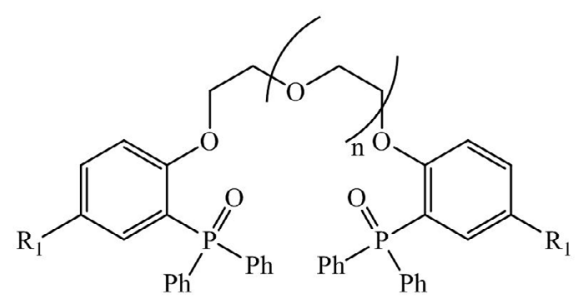

20, $n=1, \mathrm{R}_{1}=\mathrm{H} ; 21, n=1, \mathrm{R}_{1}=\mathrm{C}_{2} \mathrm{H}_{5} ; 22, n=2, \mathrm{R}_{1}=\mathrm{H}$
Природа органического растворителя также влияет и на селективность экстракции. Турановым и сотрудниками обнаружено, что при увеличении сольватирующей способности органического растворителя для системы с экстрагентом 24д увеличивается селективность экстракции катионов Р3М в следующем порядке: толуол < $<$ хлороформ < метилен хлорид. Возможно, это связано с тем, что комплексы катионов тяжелых Р3М сольватированы органическими растворителями в большей степени. При экстракции катионов соединением 24д с применением полярного растворителя эффективность экстрации увеличивается с увеличением атомного номера Р3 элемента в периодической таблице. Для толуола (менее полярного растворителя) эффективность экстракции повышается только для ряда элементов от лантана до европия, затем понижается от тербия до лютеция.

Селективность экстракции может зависеть и от количества атомов кислорода $m$ в полиэфирной цепи подандов. Увеличение $m$ в подандах 24а-24г от одного до трех понижает эффективность и селективность экстракции лантаноидов. Увеличение $m$ до четырех вызывает незначительное понижение эффективности экстракции для лантана, для остальных Р3 элементов эффективность экстракции увеличи-

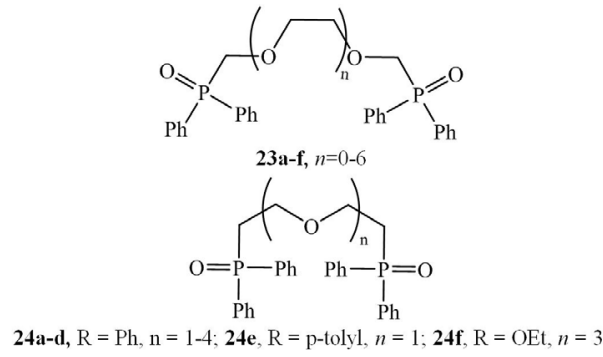




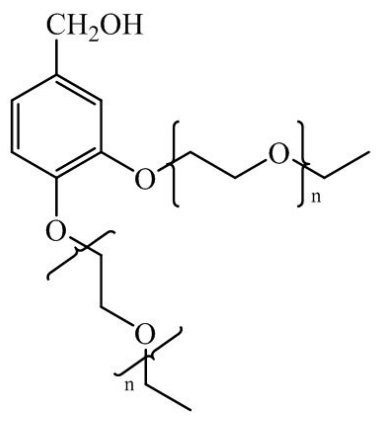

25

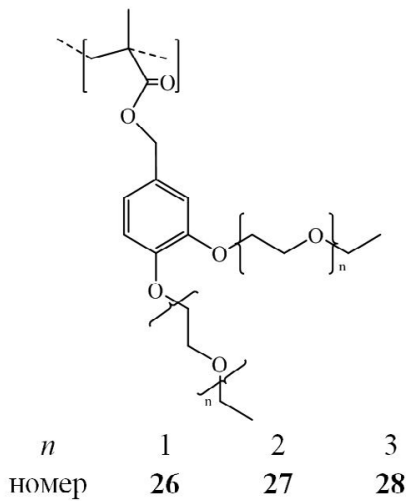

в отличие от краун-эфирсодержащих полимеров, полимеры, содержащие поданды, способны к более эффективной экстракции лантаноидов в воде. Увеличение эффективности экстракции лантаноидов как в воде, так и в ацетонитриле наблюдается в ряду полимеров $26<27<28$.

Резюмируя вышеизложенное, стоит отметить, что наиболее эффективными экстрагентами для РЗМ являются фосфорил-содержащие поданды, селективность которых может зависеть как от количества атомов кислорода в полиэфирной цепочке поданда, так и от природы органического растворителя.

\section{Экстракция катионов РЗМ модифицированными каликс[n]аренами}

С развитием атомно-энергетической отрасли остро возник вопрос о ликвидации и переработке ядерных отходов. Разделение актиноидов от лантаноидов является важным этапом перед осуществлением трансмутационной технологии превращения актиноидов. Поэтому для экстракции радиоактивных элементов из ядерных отходов был испытан ряд селективных экстрагентов, например, монодентантные фосфорорганические экстраген- ты (триоктилфосфиноксид, ТОФО) [17]. Однако они проявляли низкую эффективность и недостаточную избирательность. Поэтому возникла идея присоединения фосфорильной группы на жесткую платформу каликсарена, чтобы воспользоваться синергетическим эффектом для увеличения эффективности и селективности экстракции [18]. Ранее уже были хорошо изучены и описаны производные каликсарена, содержащие карбомо- 

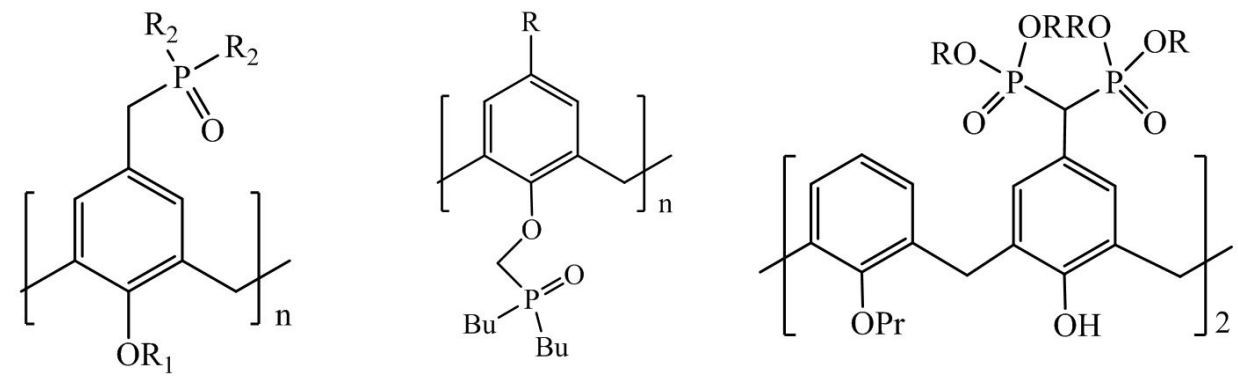

\begin{tabular}{l|l|l|l}
$n$ & \multicolumn{1}{|c|}{$\mathrm{R}_{1}$} & \multicolumn{1}{|c}{$\mathrm{R}_{2}$} & \\
\hline 4 & пропил & метил & $\mathbf{2 9 a}$ \\
\hline & & этил & $\mathbf{2 9 6}$ \\
\hline & & пропил & $\mathbf{2 9}$ \\
\hline & & изопропил & $\mathbf{2 9}$ \\
\hline 4 & гексил & этил & $\mathbf{3 0 a}$ \\
\hline & & бутил & $\mathbf{3 0 6}$ \\
\hline 6 & метил & этил & $\mathbf{3 1 a}$ \\
\hline & & бутил & $\mathbf{3 1 6}$
\end{tabular}

\begin{tabular}{|c|c|c|c|c|}
\hline$n$ & $\mathrm{R}$ & & $\mathrm{R}$ & \\
\hline 4 & $\mathrm{H}$ & $32 a$ & метил & $35 a$ \\
\hline 4 & третбутил & 326 & этил & 356 \\
\hline 5 & третбутил & $33 a$ & пропил & 35B \\
\hline \multirow[t]{2}{*}{6} & $\mathrm{H}$ & $34 a$ & изопропил & $35 \Gamma$ \\
\hline & & & бутил & $35 д$ \\
\hline
\end{tabular}

илметилфосфин оксиды в различных положениях фрагментов каликсарена $[19,20]$ так же, как и некоторые каликсарены с фосфиновыми оксидами по нижнему ободу [21, 23].

M. Karavan и сотрудники изучили комплексообразующие свойства фосфонат производных каликс $[n]$ аренов 29-36 по отношению к некоторым актиноидам и лантаноидам [23]. Анализ экспериментальных данных экстракции катионов из раствора азотной кислоты в $m$-нитробензотрифториде ( $m$-NBTF) показал, что эффективность экстракции каликсаренами с фосфиновыми заместителеми в верхнем ободе 296 и 29д для катионов ${ }^{152} \mathrm{Eu}$ превышает таковую для ${ }^{241} \mathrm{Am}$. Однако увеличение концентрации азотной кислоты в растворе приводит к уменьшению значения коэффициента извлечения для соединения 29e; для 29б

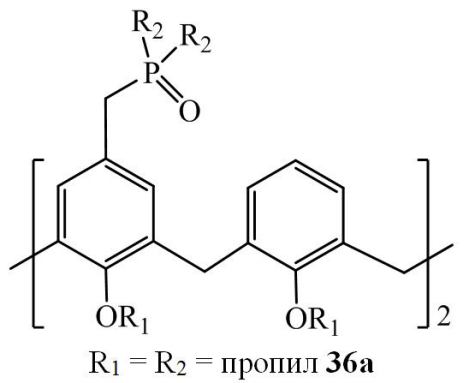

наблюдается постепенное увеличение коэффициента до 0,9 $\mathrm{M} \mathrm{HNO}_{3}$, которое затем сменяется резким уменьшением.

Из ряда каликсаренов с фосфиновыми заместителями по нижнему ободу 32a, 32б, 33a и 34a наибольшей экстракционной эффективностью для ${ }^{241} \mathrm{Am}$ и ${ }^{152} \mathrm{Eu}$ обладает $n$-третбутилкаликс[5] арен 33а.

Среди каликсаренов с фосфонатными заместителями в верхнем ободе 35a-35д максимальным значением коэффициента извлечения для европия и америция обладает 35в.

Коэффициенты извлечения ${ }^{241} \mathrm{Am}$ и ${ }^{152} \mathrm{Eu}$ были определены радиометриче- 
ски используя $\gamma$-излучение соответствующих изотопов [22].

Еще один пример синтеза селективных экстрагентов на основе каликс[4]арена для разделения актиноидов от лантаноидов был описан Ansari и сотрудниками $[24,25]$. Они получили серию пиразин-замещенных каликсаренов 37-39 и изучили их эффективность для экстракции катиона $\mathrm{Eu}^{3+}$ из водного раствора азотной кислоты.

По данным исследований, эффективность экстракции катиона европия соединениями 37-39 можно отобразить в следующей последовательности: $37<38<39$. Такие результаты можно объяснить влиянием природы заместителя пиразинового фрагмента соединений 37-39. Исследователями также установлено, что соотношение между соединениями 37-39 и катионом $\mathrm{Eu}^{3+}$ в образовавшихся комплексах равно 1:1.

Однако, по мнению Н. Huang и сотрудников, присутствие атома фосфора в структуре молекулы экстрагента не позволяет полностью его сжечь, превращаясь в накапливающиеся твердые отходы [26]. Наилучшими экстрагентами в таком случае являются соединения, состоящие только из атомов С, Н, О и $\mathrm{N}$, которые превратятся в газообразные продукты после утилизации. Подходящими под «принцип CHON» считались перспективные, легко синтезируемые соединения для экстракции актиноидов из растворов кислот - дигликольамиды (DGA) [27]. Но вследствие их низкой избирательности DGA не могут быть использованы для разделения актиноидов и лантаноидов. Введение в молекулу каликс[4]арена дигликольамида - способ
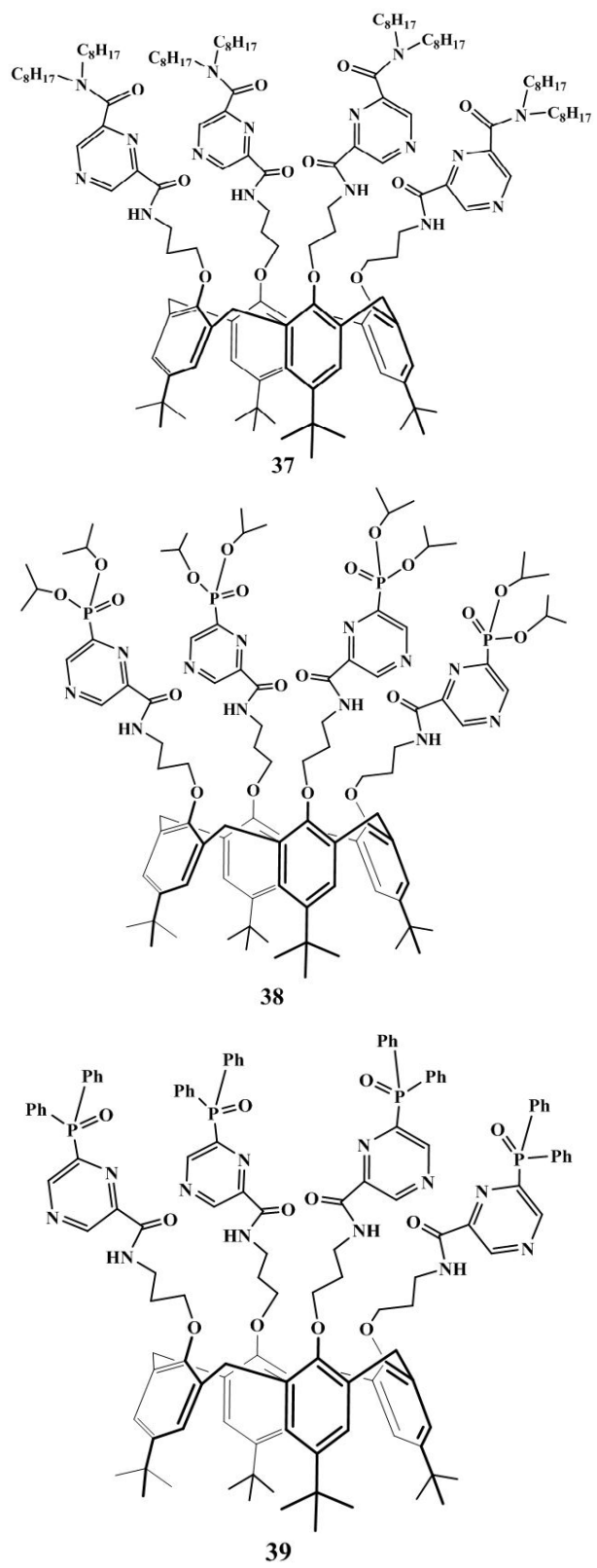

получения перспективного соединения 43 для разделения актиноидов и лантаноидов, который выбрали Huang и сотрудники.

Синтез каликс[4]арен-BDGA 43 осуществлен в соответствии со схемой, где соединения 40 и 42 были по- 


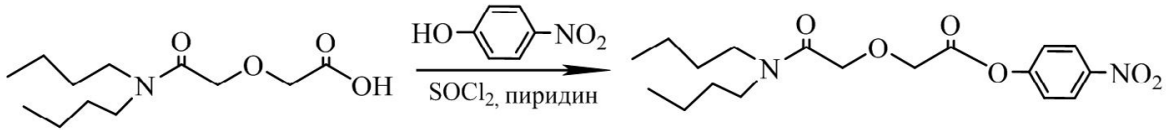

4041
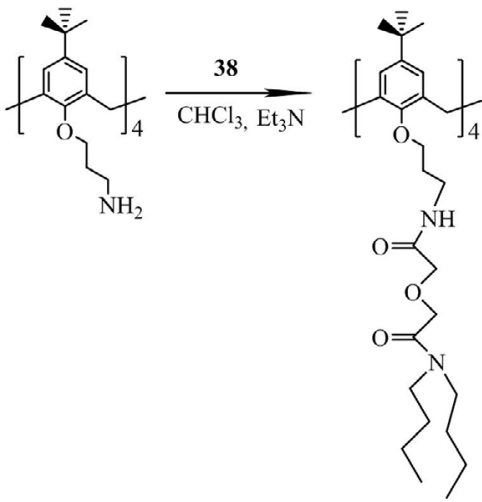

4243

лучены по ранее описанным методикам $[28,29]$.

Исследование экстракции Am(III) и $\mathrm{Eu}(\mathrm{III})$ из раствора азотной кислоты соединением 43 проводилось, используя 95 \% керосин / 5 \% н-октанол как дилюент. Результаты показали, что значение коэффициента извлечения для $\mathrm{Am}(\mathrm{III})$ и $\mathrm{Eu}(\mathrm{III})$ увеличивается с повышением концентрации азотной кислоты в интервале от 0,5-5,0 моль/л. Лиганд 43 проявил более высокую селективность для $\mathrm{Eu}(\mathrm{III})$, чем для $\mathrm{Am}(\mathrm{III})$ с фактором разделения $\mathrm{SF}_{\mathrm{Am}(\mathrm{III})}$ Еu(III) В пределах 4,5-7,3, что свидетельствует о его эффективности при разделении катионов лантаноидов и актиноидов [30].

Таким образом, модифицированные каликсарены занимают одну из лидирующих позиций среди высокоэффективных и селективных экстрагентов катионов редкоземельных металлов.

\section{Дигликольамиды - экстрагенты для разделения актиноидов и лантаноидов}

Дигликольамиды и их производные, являющиеся перспективными экстрагентами для извлечения низших актинидов из растворов азотной кислоты, были описаны H. Stephan и коллегами в 1991 году [31]. Присутствие эфирного кислорода между двумя амидными группами в DGA повышает извлечение низших актиноидов вследствие активного образования тридентантных комплексов. Как наиболее перспективные экстрагенты для низших актинидов среди дигликольамидов рассматриваются N,N,N',N'тетраоктилдигликольамид (ТОДГА) 44ж и $\mathrm{N}, \mathrm{N}, \mathrm{N}^{\prime}, \mathrm{N}^{\prime}$-тетра-2-этилгексилдигликольамид (ТЭГДГА) 44к [32, 33].
Это объясняется влиянием природы алкильных заместителей дигликольамида.

Влияние алкильных заместителей и природы дилюента на экстракцию лантаноидов и актиноидов дигликольамидами 44a-м было изучено Y. Sasaki и коллегами [34]. Ими установлено, что соединения с разветвленной алкильной цепью и несимметричными алкил-фенильными амидными группами имеют сравнительно низкий коэффициент извлечения катионов, чем глигольамиды с линейными углеводородными заместителями. Исследование экстракции лантанидов ТФДГА, ТОДГА, ТДдДГА, ТЭГДГА и 
ДМДФДГА проводились в шести растворителях (нитробензол, дихлорэтан, октанол, хлороформ, толуол, додекан), используя 0,04-0,1 М дигликольамида и 1 М раствор азотной кислоты. За исключением экстрагирования ТФДГА в толуоле, ДМДФДГА в хлороформе и толуоле и ТЭГДГА в шести дилюентах наблюдалось постепенное увеличение коэффициента извлечения лантанидов в порядке увеличения их атомного номера от La до Но, затем значение коэффициента понижается для катионов Er-Lu. Также стоит отметить, что ТОДГА или ТДдДГА, растворенные в нитробензоле, октаноле и додекане, имеют фактор разделения $\mathrm{SF}(\mathrm{Lu} / \mathrm{La})$ более 100 , чем подтверждают использование этих дигликольамидов для селективного разделения лантаноидов. Экстракция лантаноидов в хлороформ или толуол показала не только низкое значение коэффициента извлечения, но и фактора разделения SF(Ln/La).

Таким образом, важным условием, влияющим на эффективность экстрак-

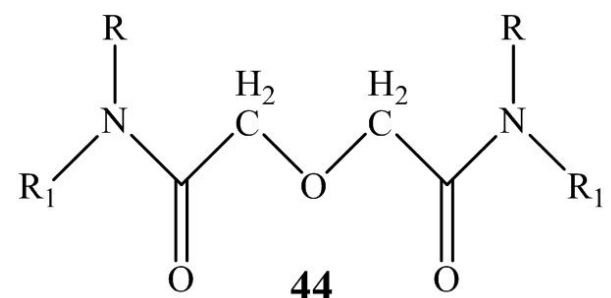

\begin{tabular}{l|l|l}
$\mathrm{R}, \mathrm{R}_{1}$ & тетраметил & ТМДГА 44a \\
\hline & тетраэтил & ТЭДГА 446 \\
\hline & тетрапропил & ТПДГА 44в \\
\hline & тетрабутил & ТБДГА 44г \\
\hline & тетраамил & ТАДГА 44д \\
\hline & тетрагексил & ТГДГА 44e \\
\hline & тетраоктил & ТОДГА 44ж \\
\hline & тетрадецил & ТДДГА 443 \\
\hline & тетра-2-этилгексил & ТЭГДГА 44к \\
\hline & N,N'-диметил- & ДМДФДГА \\
& N,N'-дифенил & $\mathbf{4 4 л}$ \\
\hline & тетрафенил & ТФДГА 44м
\end{tabular}

ции лантаноидов дигликольамидами, является природа алкильных заместителей дигликольамида и используемого дилюента.

\section{Экстракция лантанидов органофосфорными экстрагентами}

Трибутилфосфат ТБФ и трифенилфосфиноксид ТОФО с давних времен являются объектами для изучения их экстрактивной активности по отношению к катионам редкоземельных металлов [35]. Е. Jorjani и сотрудники изучили эффективность экстракции трибутилфосфатом катионов иттрия, лантана, церия и неодима - главных компонентов отходов переработки железной руды.

Исследования показали, что при использовании различных концентраций раствора ТБФ в керосине (от 0,73 до 3,65 моль•л ${ }^{-1}$ ) наблюдалось увеличение значения коэффициента извлечения до концентрации ТБФ 3,65 моль $\pi^{-1}$ [36].

При изучении экстракции катионов РЗМ органофосфорными экстрагентами исследователи уделяют внимание синергетическому эффекту. Синергетическая экстракция трехвалентных лантанидов представляет большой интерес благодаря высокой эффективности экстракции катионов хелатирующим агентом в присутствии нейтрального донора. Множество изученных жидкофазных экстракционных процессов, которые имели си- 
<smiles>CC1=NN(c2ccc([N+](=O)[O-])cc2)C(=O)C1[N+](=O)[O-]</smiles>

45

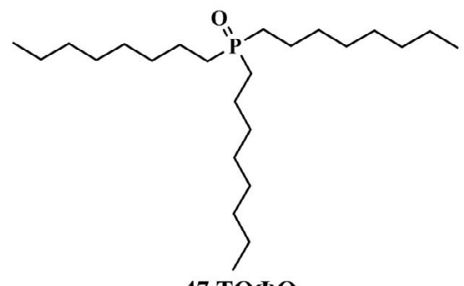

47 ТОФО нергетический характер, выполнены с использованием монодентантных соединений (например, триоктилфосфин оксид, ТОФО и $\beta$-дикетоны). Umetani и Freiser изучили смешанную лиганд-хелат экстракцию лантанидов с 1-фенил-3-метил-4-(трифторацетил)5-пиразолоном и некоторыми фосфин оксидами [37].

Экстракция лантанидов смесью пикролоновой кислоты 45 с различными фосфорорганическими нейтральными донорами была изучена А. Али и сотрудниками [38]. В одной из своих работ они опубликовали дан-

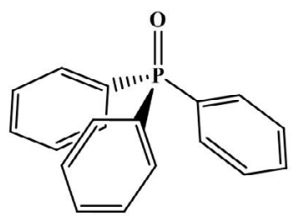

46 ТФФО

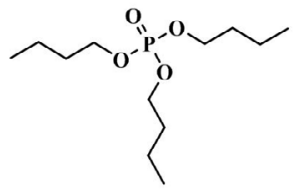

48 ТБФ

\section{Заключение}

Органофосфорные экстрагенты обрели свою популярность благодаря относительно простым методам получения и дешевизне. По селективности они во многом уступают краун-эфирам и каликсаренам. Однако способность органофосфорных соединений к синергетической экстракции катионов служит причиной для дальнейшего их изучения [42]. ные исследований синергетической экстракции $\mathrm{Eu}(\mathrm{III})$ из смеси катионов переходных двухвалентных металлов с применением растворенной в хлороформе смеси пикролоновой кислоты и ТОФО, ТФФО и ТБФ [39]. Извлеченные частицы были охарактеризованы как $\mathrm{Eu}(\mathrm{PA}) 3 \cdot 2 \mathrm{TO} Ф, \mathrm{Eu}(\mathrm{PA})_{3} \cdot 2 \mathrm{~T} Ф Ф О$, и $\mathrm{Eu}(\mathrm{PA})_{3} \cdot$ ТБФ [40]. Наиболее эффективной экстрагирующей смесью для европия оказалась смесь пикролоновой кислоты и ТОФО, менее эффективной - ПК и ТФФО. Наименьшую способностью к экстракции европия показала смесь ПК и ТБФ [41].
Наиболее перспективными экстрагентами для Р3М на сегодняшний день являются краун-эфиры, каликсарены, поданды, дигликольамиды и органофосфорные соединения $[43,44]$. Модификация (в том числе и объединение) их структур дает возможность получить широкий спектр экстрагентов, избирательно связывающих катионы Р3М. 


\section{References}

1. Eliseeva S. V., Bunzli J.-C. G. Rare earths: Jewels for functional materials of the future. New J. Chem. 2011; 35(6):1165-1176. DOI: 10.1039/c0nj00969e.

2. Pyrzynska K., Kubiak A., Wysocka I. Application of solid phase extraction procedures for rare earth elements determination in environmental samples. Talanta. 2016;154:15-22. DOI: 10.1016/j.talanta.2016.03.022.

3. Tan Q., Li J., Zeng X. Rare Earth Elements Recovery from Waste Fluorescent Lamps: A Review. Critical Reviews in Environmental Science and Technology. 2015;45 (7):749-776.

4. Abrahami S. T., Xiao Y., Yang Y. Rare-earth elements recovery from post-consumer hard-disc drives. Transactions of the Institutions of Mining and Metallurgy, Section C: Mineral Processing and Extractive Metallurgy. 2015;124 (2):106-115.

5. Kolarik Z. Ionic Liquids: How Far Do they Extend the Potential of Solvent Extraction of f-Elements? Solvent Extraction and Ion Exchange. 2016;31(1):24-60.

6. Pedersen C. J. Cyclic polyethers and their complexes with metal salts. Journal of the American Chemical Society. 1967;89(26):7017-7036. DOI:10.1021/ja01002a035.

7. Horwitz E. P., Dietz M. L., Fisher D. E. Separation and preconcentration of strontium from biological, environmental, and nuclear waste samples by extraction chromatography using a crown ether. Analytical Chemistry. 1991;63(5):522-525.

8. Riahi F., Bagherzadeh M. Separation of some lanthanide (III) Ions by using 18-crowns-6 derivatives from acidic solution. Journal of Applied Sciences. 2010;10(16):1781-1787.

9. Demin S. V., Zhilov V. I., Tsivadze A. Yu., Yakshin V. V., Vilkova O. N., Tsarenko N. A. Extraction of rare-earth elements by alkylated dibenzo-18-crown-6 and dicyclohexano-18-crown-6 from acid solutions. Russian Journal of Inorganic Chemistry. 2006;51(10):1678-1681.

10. Rey J., Garcна F. C., Garcha J. M. Reactive \& Functional Polymers. 2011;71:948-957.

11. Turanov A. N., Karandashev V. K., Baulin V. E. Extraction of rare earth elements with phosphoryl-containing lariat crown ether in the presence of ionic liquids. Russian Journal of Inorganic Chemistry. 2012;57(2):292-296. DOI: 10.1134/ S0036023612020246.

12. Solov'ev V. P., Govorkova L. V., Raevskii O. A., Baulin V. E., Syundyukova V. Kh., Tsvetkov E. N. Phosphorus-containing podands. 4. Complexation of calcium chloride in alcohol at $298 \mathrm{~K}$ by solution calorimetry. Bulletin of the Academy of Sciences of the USSR. Division of Chemical Science. 1989;38(4):731-734.

13. RF Patent 2391 349. Tsivadze A. Yu., Baulin V. E., Baulin D. V., et al., Applied December 3, 2008, Published June 10, 2010, Byull. Izobret., 2010, no. 16.

14. RF Patent 2352 576. Baulin D. V., Baulin V. E., Safiulina A. M. and Tsivadze G. A., Applied March 23, 2008, Published April 24, 2009, Byull. Izobret., 2009, no. 11.

15. Turanov A. N., Karandashev V. K., Baulin V. E. Extraction of REEs(III), U(VI) and Th(IV) with acidic phosphoryl- containing podands from nitric acid solutions. $R a-$ diochemistry. 2014;56(1):22-26. DOI: 10.1134/S1066362214010056. 
16. Turanov A. N., Karandashev V. K., Baulin V. E. Extraction of rare-earth nitrates by phosphoryl podands. Russian Journal of Inorganic Chemistry. 2006;51(11):18291835. DOI: 10.1134/S0036023606110210.

17. Arduini A., Böhmer V., Delmau L., Shivanyuk A., Ugozzoli F. Rigidified calixarenes bearing four carbamoylmethylphosphineoxide or carbamoylmethylphosphoryl functions at the wide rim. Chemistry - A European Journal. 2000;6(12):2135-2144.

18. Arnaud-Neu F., Barboso S., Byrne D., Charbonniure L. J., Schwing-Weill M. J., Ulrich $\mathrm{G}$. Binding of lanthanides(III) and thorium(IV) by phosphorylated calixarenes. ACS Symposium Series. 2000;757:150-164.

19. Antipin I. S., Kazakova E. K., Habicher W. D., Konovalov A. I. Phosphorus-containing calixarenes. Russian Chemical Reviews. 1998;67(11):905-922. DOI: 10.1070/ RC1998v067n11ABEH000472.

20. Smirnov I. V., Shadrin A. Yu., Babain V. A., Logunov M. V., Chmutova M. K., Kal'Tchenko V. I. Calixarene-containing extraction mixture for the combined extraction of $\mathrm{Cs}, \mathrm{Sr}, \mathrm{Pu}$, and $\mathrm{Am}$ from alkaline radioactive wastes. ACS Symposium Series. 2000;757:107-111.

21. Arnaud-Neu F., Böhmer V., Dozol J.-F., Simon N., Vogt W. Calixarenes with diphenylphosphoryl acetamide functions at the upper rim. A new class of highly efficient extractants for lanthanides and actinides. Journal of the Chemical Society. Perkin Transactions 2. 1996;6:1175-1182.

22. Arnaud-Neu F., Browne J. K., Byrne D., Schwing-Weill M. J., Walker A. Extraction and complexation of alkali, alkaline earth, and F-element cations by calixaryl phosphine oxides. Chemistry - A European Journal. 1999; 5(1):175-186. DOI: 10.1002/ (SICI)1521- 3765(19990104)5:1<175.

23. Karavan M., Arnaud-Neu F., Hubscher-Bruder V., Smirnov I., Kalchenko V. Novel phosphorylated calixarenes for the recognition of f-elements. Journal of Inclusion Phenomena and Macrocyclic Chemistry. 2010;66 (1):113-123. DOI: 10.1007/s10847009-9660-4.

24. Ansari S. A., Pathak P. N., Manchanda V. K., Husain M. B, Prasad A. K., Parmar V. S. N,N,N',N'-Tetraoctyl diglycolamide (TODGA): A promising extractant for actinide-partitioning from high-level waste (HLW). Solvent Extraction and Ion Exchange. 2005;23(4):463-479. DOI: 10.1081/SEI-200066296.

25. Ansari S. A., Pathak P. N., Husain M., Prasad A. K., Parmar V. S., Manchanda V. K. Extraction of actinides using $\mathrm{N}, \mathrm{N}, \mathrm{N}, \mathrm{N}^{\prime}$-tetraoctyl diglycolamide (TODGA): A thermodynamic study. Radiochimica Acta . 2006;94(6-7): 307-312. DOI: 10.1524/ ract.2006.94.6.307.

26. Huang H., Ding S., Su D., Liu N., Wang J., Tan M., Fei J. High selective extraction for thorium(IV) with NTA-amide in nitric acid solution: Synthesis, solvent extraction and structure studies. Separation and Purification Technology. 2015;138: 65-70.

27. Ravi J., Prathibha T., Venkatesan K. A., Antony M. P., Srinivasan T. G., Vasudeva Rao P. R. Third phase formation of neodymium (III) and nitric acid in unsymmetrical N,N-di-2-ethylhexyl-N',N'-dioctyldiglycolamide. Separation and Purification Technology. 2012; 85:96-100. DOI: 10.1016/j.seppur.2011.09.053. 
28. Taktak S., Weissleder R., Josephson L. Electrode chemistry yields a nanoparticlebased NMR sensor for calcium. Langmuir. 2008;24(14):7596-7598. DOI: 10.1021/ la8006298.

29. Casnati A., Della Ca N., Fontanella M., Sansone F., Ugozzoli F., Ungaro R., Liger K., Dozol J.-F. Calixarene-based picolinamide extractants for selective An/Ln separation from radioactive waste. European Journal of Organic Chemistry. 2005;11: 23382348. DOI: 10.1002/ejoc.200400793.

30. Huang H., Ding S., Liu N., Su D., Huang S. Extraction of trivalent americium and europium from nitric acid solution with a calixarene-based diglycolamide. Separation and Purification Technology. 2014;123: 235-240.

31. Stephan H., Gloe K., Mühl P., Beger J. Liquid-liquid extraction of metal ions with amido podands. Solvent Extraction and Ion Exchange. 1991;9(3): 459-469.

32. Magnusson D., Christiansen B., Glatz J.-P., Malmbeck R., Modolo G., SerranoPurroy D., Sorel C. Demonstration of a TODGA based extraction process for the partitioning of minor actinides from a PUREX raffinate part III: Centrifugal contactor run using genuine fuel solution. Solvent Extraction and Ion Exchange. 2009; 27(1): 26-35. DOI: 10.1080/07366290802544726.

33. Gujar R. B., Ansari S. A., Prabhu D. R., Raut D. R., Pathak P. N., Sengupta A., Thulasidas S. K., Mohapatra P. K., Manchanda V. K. Demonstration of t2ehdga based process for actinide partitioning part ii: Counter-current extraction studies. Solvent Extraction and Ion Exchange. 2010;28(6):764-777. DOI: 10.1080/07366299.2010.509684.

34. Sasaki Y., Sugo Y., Morita K., Nash K. L. The Effect of Alkyl Substituents on Actinide and Lanthanide Extraction by Diglycolamide Compounds. Solvent Extraction and Ion Exchange. 2015;33(7):625-641.

35. Majdan M. The separation factors of the lanthanides in the Ln(NO3)3-NH4NO3-TBP system. Effects of change in activity coefficients. Hydrometallurgy. 1994;35(2):179-185. DOI: 10.1016/0304-386X(94)90050-7.

36. Jorjani E., Shahbazi M. The production of rare earth elements group via tributyl phosphate extraction and precipitation stripping using oxalic acid. Arabian Journal of Chemistry. In Press. DOI:10.1016/j.arabjc.2012.04.002.

37. Umetani S., Freiser H. Mixed-ligand chelate extraction of lanthanides with 1-phenyl-3-methyl-4-(trifluoroacetyl)-5-pyrazolone and some phosphine oxide compounds. Inorganic Chemistry. 1987;26(19):3179-3181.

38. Habib-ur-Rehman Ali, A., Anwar J., Ahmed S. Synergistic extraction of Nd(III), Tb(III) and $\mathrm{Lu}(\mathrm{III})$ ions with a mixture of picrolonic acid and benzo-15-crown-5 in chloroform. Radiochimica Acta . 2006;94(8):475-480. DOI: 10.1524/ract.2006.94.8.475.

39. Ali A. Extraction of Eu(III) and Tm(III) with picrolonic acid in methylisobutylketone. Radiochimica Acta. 2004: 92(2):101-104.

40. Ali A. Synergistic extraction of $\mathrm{Ce}(\mathrm{III}), \mathrm{Eu}(\mathrm{III})$ and $\mathrm{Tm}$ (III) with a mixture of picrolonic acid and tributylphosphine oxide in chloroform. Radiochimica Acta. 2004;92(12): 925-929. 
41. Ali A., Ahmed M. Extraction of Sm(III), Gd(III) and Ho(III) ions with picrolonic acid in methylisobutylketone. Journal of Radioanalytical and Nuclear Chemistry. 2005;266(3):481-484.

42. Jia Q., Tong S., Li Z., Li H., Meng S. Solvent extraction of rare earth elements with mixtures of sec-octylphenoxy acetic acid and bis(2,4,4-trimethylpentyl) dithiophosphinic acid. Separation and Purification Technology. 2009;64(3):345-350.

43. Mincher B. J., Modolo G., Mezyk S. P. Review: The effects of radiation chemistry on solvent extraction 4: Separation of the trivalent actinides and considerations for radiation-resistant solvent systems. Solvent Extraction and Ion Exchange. 2010;28(4):415-436. DOI: 10.1080/07366299.2010.485548.

44. Mincher B. J., Modolo G., Mezyk S. P. Review article: The effects of radiation chemistry on solvent extraction 3: A review of actinide and lanthanide extraction. Solvent Extraction and Ion Exchange. 2009;27(5-6):579-606. DOI: $10.1080 / 07366290903114098$.

Cite this article as (как цитировать эту статью):

V. V. Kurysheva, E. V. Ivanova, P. E. Prohorova. Extractants for rare earth metals. Chimica Techno Acta. 2016; 3(2):97-120. DOI: 10.15826/chimtech.2016.3.2.008. 